\title{
Chapter 8 \\ Feasibility of Small-Scale Sago Industries in the Maluku Islands, Indonesia
}

\author{
Wardis Girsang
}

\begin{abstract}
The sago industry has a pivotal role to exploit underutilized sago starch in the sago forest but is little known in terms of the feasibility of existing sagoprocessing industries, particularly in small islands. This paper outlines the feasibility and possible future development of existing sago industries in Maluku, Indonesia. Data were collected from field observations, in-depth interviews, and focus group discussions from nine small-scale sago industries in Ambon and Seram Islands. Existing sago industries were found financially feasible in the short term but may be unsustainable over the longer term. Modern sago industries are 25 times higher in investment and operational costs but 15 times higher in production, up to 4 times higher in labor absorption, and 5 times higher in profit than that of semi-modern industry technology. However, modern sago industries are difficult to sustain because of the high price of raw material, uncertain market demand, fragile institutional development, and uncertain sago forest sustainability in the islands because the cutting of sago trees occurs about 15 times faster than that of conventional technology industry. This suggests that sustainable sago industries for food security in Maluku need adaptive technology to improve added value and to reduce operational costs and be small scale but intensive and efficient.
\end{abstract}

\subsection{Introduction}

Food security and population growth are a challenge to human development in the world, particularly in developing countries like Indonesia. The world population is projected to increase from seven billion in 2010 to nine billion in 2050 suggesting that food production needs to increase some $70 \%$ over that period to fulfill projected food demand (National Food Security Board 2011). However, due to the impact of climate change on agriculture and fisheries, food production will probably decrease. As part of the developing world, Indonesia's population reached 250 million in 2016 and is increasing steadily; therefore, future food availability will be at risk,

\footnotetext{
W. Girsang $(\triangle)$

Faculty of Agriculture, University of Pattimura, Ambon, Indonesia

e-mail: girsangwardis@faperta.unpatti.ac.id; girsangwardis@yahoo.com
} 
particularly in small islands like the Malukus. Small islands are vulnerable to food insecurity because they are relatively isolated, are less developed and have limited accessibility and connectivity within and between islands. In this case, staple food in small islands should be based on local food products; however, staple food has changed considerably from sago, maize, and tubers to rice as the national staple food. This situation will endanger local staple food and create dependency on imported rice and vulnerability of food security (Fig. 8.1).

Rice production in the Malukus is only 70,000 mt/year, satisfying around $40 \%$ of total rice demand. To avoid consumption dependency on imported rice, therefore, local food crops, particularly sago starch, have the potential to be considered as an alternative strategy to sustain food security in small islands. In Indonesia, around 2 million ha of sago palms exist which could theoretically produce 60 million $\mathrm{mt}$ of sago starch or twice the national rice production. Unlike rice, sago palms have special characteristics: (1) they are environmentally friendly trees which conserve water; (2) they are more resistant to climate change impacts, pests, and diseases (Amien 2011); (3) they grow well in marginal lands (Louhenapessy 1992); (4) they are self-regenerating trees which grow naturally in clusters along the rivers and on level areas (Ellen 2006); and (5) they can also contribute to bioethanol and sugar production as well as to reduce global warming (Ishizaki 1997; Bujang 2010).

Because food security is a crucial issue in small islands, therefore the great potential of sago forests in the Malukus should prioritize for food security, and the government should implement a policy to protect them. In fact, the potential of sago is underutilized, while current government policy follows national food policy that is to expand new paddy rice areas by up to 6000 ha in the next 6 years. As a consequence, sago forests will probably be cleared and replaced by rice cultivation. In addition, the rapid pace of sago tree cutting by sago starch industries may exceed natural regeneration and cultivation. To some extent, sago forests are unsustainable in some areas and unutilized in others. Therefore, the feasibility of small-scale sago industries in small islands needs to be assessed.

\subsection{Methodology}

Sago forest can be found in several regions of the Malukus, including the islands of Seram, Ambon-Lease, Buru, Kei, and Aru, and a limited area in the Tanimbar Islands. Research for this study was carried out in Seram and Ambon islands. These two islands were selected because sago industries are found there and they have relatively good accessibility to Ambon, the capital of Maluku Province.

Nine sago industries were studied: seven in Ambon and two in Seram. The sago industries in Ambon consist of five wet sago starch producers and two sago food producers. One wet sago starch producer uses traditional technology, which is called nani (a traditional handmade tool that is made from small bamboo which is added with iron ring at the top and designed into L-shape to extract pith from the body of sago tree), and three producers use semi-modern technology, while the fifth 


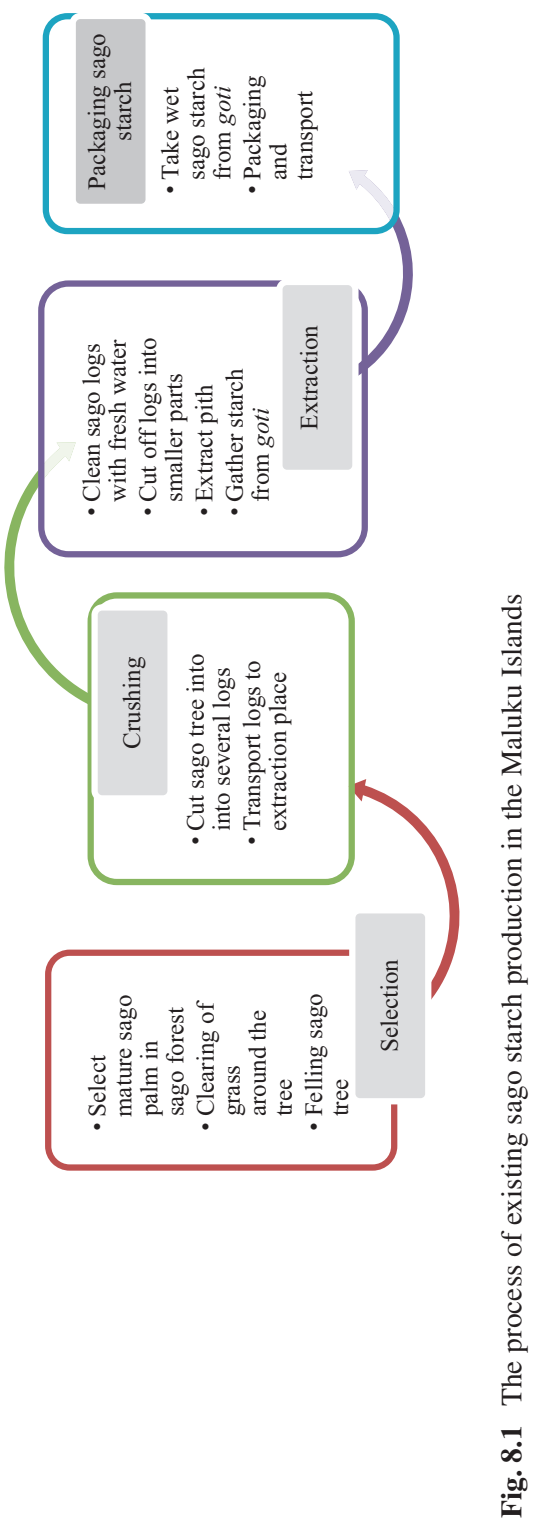


employs modern technology. Traditional technology is mobile, using simple tools, without machines and wage labor; semi-modern technology is mobile, using sago processing machines and sharing wage labor. Modern technology is immobile, using large machines and wage labor. The two sago food producers make baked sago (local name sago lempeng) using semi-modern technology and sago noodle (SN) employing modern sago food processing technology. Meanwhile, the two examples of modern sago industries in Seram use modern sago-processing technology, exporting wet sago starch to Java islands.

To collect primary and secondary data, a questionnaire was designed and applied by well-trained research assistants in the field. Field observations, focus group discussions, and in-depth interviews were developed as mixed methods to collect data from individuals and sago group members. Small-scale businesses and home industries were the unit of analysis for the sago industry in order to assess the feasibility of small-scale sago industries (Ibrahim 1985).

\subsection{Results and Discussions}

\subsubsection{The Potential of Sago Palm}

The area of sago palm in the world is estimated at 2,474,000 ha (Flach 1984); it is assumed that sago palm productivity could be improved up to $30 \mathrm{mt} / \mathrm{ha}$ (Bujang 2010); therefore, sago palms have the potential to produce 74.2 million mt of starch. As sago starch consumption is approximately $180 \mathrm{~kg} / \mathrm{capita} /$ year (Yamamoto 2011), sago palm is theoretically able to feed some 412.3 million people per year in the world. This indicates that sago is a solution to the problem of food insecurity. Haryanto and Pangloli (1992) estimated that the sago palm area in Indonesia was approximately 851,260 ha, whereas Flach estimated around 1.25 million ha with about 154,000 ha classified as semi-cultivated (Flach 1983 in Bintoro et al. 2013). Other studies set the sago palm area in Indonesia at around 1,127,630 ha with 90\% found in Papua Province (Jong and Widjoyo 2007). In the Malukus, Alfons and Bustaman (2005) estimated around 31,360 ha, Provincial Central Bureau of Statistics noted around 52,000 ha (CBS 2012), whereas Flach (1997) and Bintoro (2011) estimated around 60,000 ha. Based on the previous sago area data evaluation in different areas and times (Alfons and Bustaman 2005; BPPS Maluku 2009; Bintoro 2011; CBS 2012), it can be argued that the total area of sago in the Malukus is probably about 64,205 ha which could potentially produce around $500,800 \mathrm{mt}$ of dry sago starch (Table 8.1).

Based on a nutrition security perspective, the potential of sago starch in Maluku could be around $1593 \mathrm{kcal}$ per capita/day or $145 \%$ of total need of 1100 calorie per capita/day for the 1.8 million people living in the Malukus. Due to sago land conversion, up to $30 \%$ of the total area is now in rice fields, oil palms, resettlement villages, government infrastructures, and other agricultural crops; the actual productive 


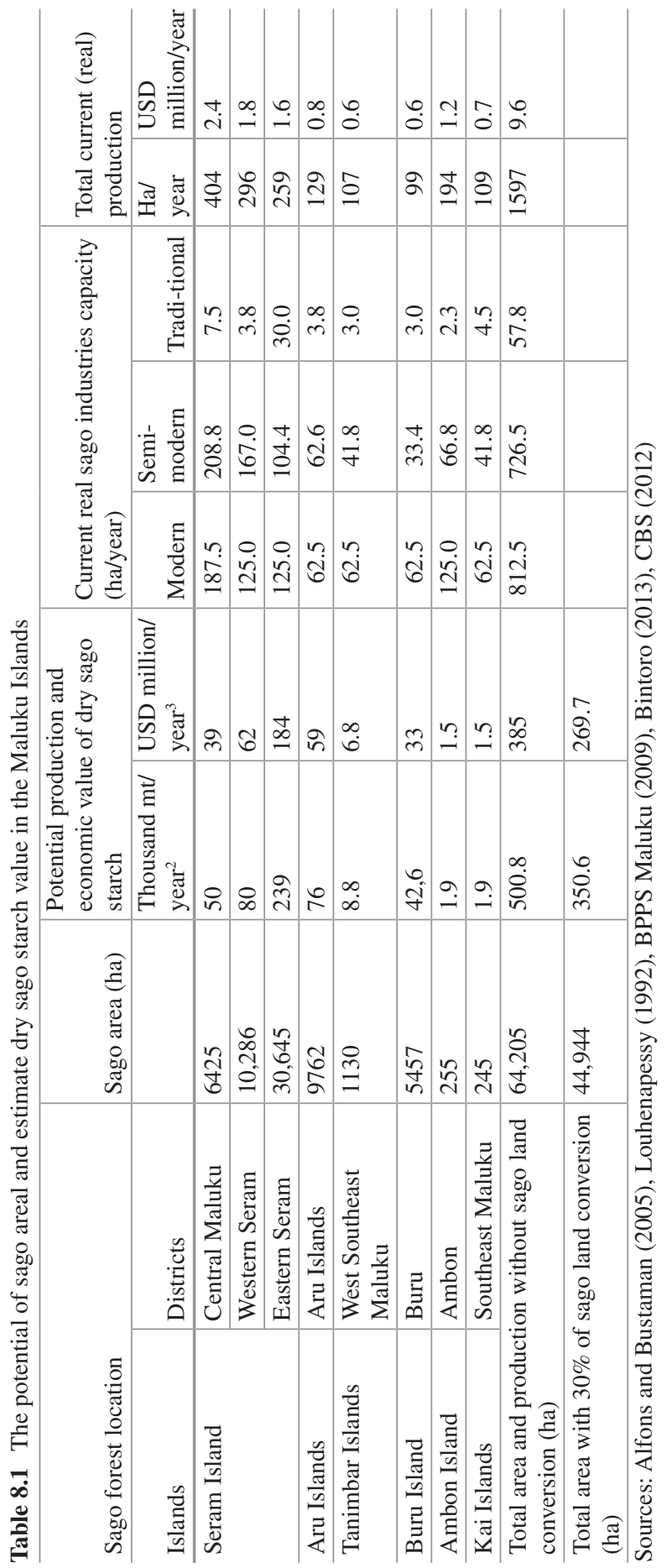


sago area is estimated to have decreased considerably to around 44,944 ha, potentially producing 350,559 mt/year with an economic value of around USD 269.7 million per year.

It is estimated that the actual sago forest exploitation is around 1597 ha or $4 \%$ of total sago forests. This implies that the remaining $96 \%$ of sago area is underutilized with a theoretical economic loss of around USD 260.1 million/year. To achieve maximum sustainable yield of the sago forests in the Malukus, sago farmers need to harvest a maximum of about 8989 ha/year to produce around 70,112 mt of dry sago starch. This means that there needs to be land protection, revitalization, zonation, and consolidation of the existing sago forest areas and the creation of infrastructural systems to increase sago value chain and to reduce transportation and the other operational costs within and between sago forests.

\subsubsection{Feasibility Small-Scale Sago Industries}

\subsubsection{Production Technology}

Previously, most sago studies in the Malukus were focused on upstream subsystems including soil types, wild stand management practices, total area, types of sago palms, and sago cultivation (Louhenapessy 1992; BPPS 2009). Very little research on sago industries was done in line with well-designed sago production and promotional development that involved cultural, environmental, and educational values (Papilaya 2009) within the downstream subsystems. Optimizing the use of sago palm can be accomplished through developing knowledge and harvest technology, sago processing, and product development to increase added value and competitiveness of local food products (Girsang and Papilaya 2009). Generally, existing sago palm harvesting and starch processing are divided into four steps: (1) determining the stage of the sago palm maturity for felling, (2) cutting the trunk and collecting the pith, (3) extracting sago starch, and (4) packaging and storage. Rumalatu (1992) identified three criteria as to local knowledge for the selection of high starch sago trees. First, maputi is the best time to harvest tuni sago (Metroxylon rumphii) which is indicated by yellow leaf stalks, smaller young leaves, and decline in thorn development. Tuni sago is one of the five sago types with local names in Maluku: ihur, duri rotan, makanaru, and molat. Second, maputi masa is indicated by the white and yellow color of leaf stalks and flowers beginning to develop; this is the best time to harvest ihur sago. Third, siri buah stage is signaled by fully developed flowers.

Traditional technology enables sago farmers to cut one sago tree every 2 weeks, using an ax without cutting into the smaller sago stems and then using nani (a traditional handmade technology tool that is made from small bamboo including iron ring at the top of the bamboo which is designed like L-shape to extract sago pith from the body of sago tree) and sahane (a traditional tool that is made from sago branch/frond to extract sago starch from pith and a fine nylon net to filter sago starch that flows to the sago starch storage). This technology was in use by farmers 
before the 1980s and then was replaced by semi-modern industry. Semi-modern technology uses chainsaws to fell sago palms and cut them into 1-m-long sections. A grater machine is employed to process the sago pith, and a receptacle called a goti, made from thick plastic material, collects the sago starch. This is a place for wet sago starch storage. Semi-modern technology was first adopted by sago farmers in the 1980s and increased considerably in the 1990s. Different from the previous technology, modern technology has a direct, automatic, and integrated process of extracting sago, with water pumped from a well to the sago extractors, and then the sago starch flows directly through a pipe into a large sago starch storage tank (goti) made from permanent materials.

The sago production capacity of traditional technology is estimated around $6 \mathrm{mt} /$ year or 30 sago trees/year, whereas semi-modern and modern technology can produce up to $45 \mathrm{mt}$ and $480 \mathrm{mt} / \mathrm{year}$, respectively, equivalent to cutting 167 and 2500 trees/year, respectively. In this case, the rapidity of cutting sago palms for semi-modern technology is almost 5.6 times faster than the conventional, while the speed of modern technology was around 15 times faster than that of semi-modern technology. The production capacity of semi-modern technology is 7.5 times higher than traditional, while modern technology is almost 11 times greater than semimodern technology production capacity. Even though traditional technology is known as time-consuming, people perceive that the quality of sago starch from traditional technology is finer, more delicious and batali (purer in sago starch), and most suited to local taste and culture. Probably this suggests that different technology prototypes will produce different qualities of sago starch.

Table 8.2 compares average investment cost data based on the technology level. For modern technology, the cost is 17 times higher than that of semi-modern technology, whereas the investment costs of the sago noodle industry is almost 46 times higher than that of semi-modern sago (lempeng sago) technology. Due to the high investment costs, the number of modern sago-processing industries is less than ten, with capital sourced from personal and family savings, financial institutions, and government aid.

\subsubsection{Investment and Production Costs}

Of the total, the operational costs for semi-modern technology are $40 \%$, mainly for labor for cutting trees, extracting, packaging, and transportation. The labor wage is the same as the minimum provincial wage, around USD 300/month. The next cost is $25 \%$ for rental of chainsaws and grater machines, $20 \%$ for raw material, and the remaining $15 \%$ for fuel/gasoline. Because sago processing companies have no sago palm forest, they have to buy every single sago tree from its owner. The prices of sago palms vary from IDR 100,000 (USD 7.6) up to IDR 150,000 (USD 11.5) per tree. To some extent, sago palm owners prefer a share of the sago starch produced, a practice called maаnu, a shared harvesting systems. In this case, the owner of the sago palm will get one-third while the other two-thirds going to the sago starch processor. 


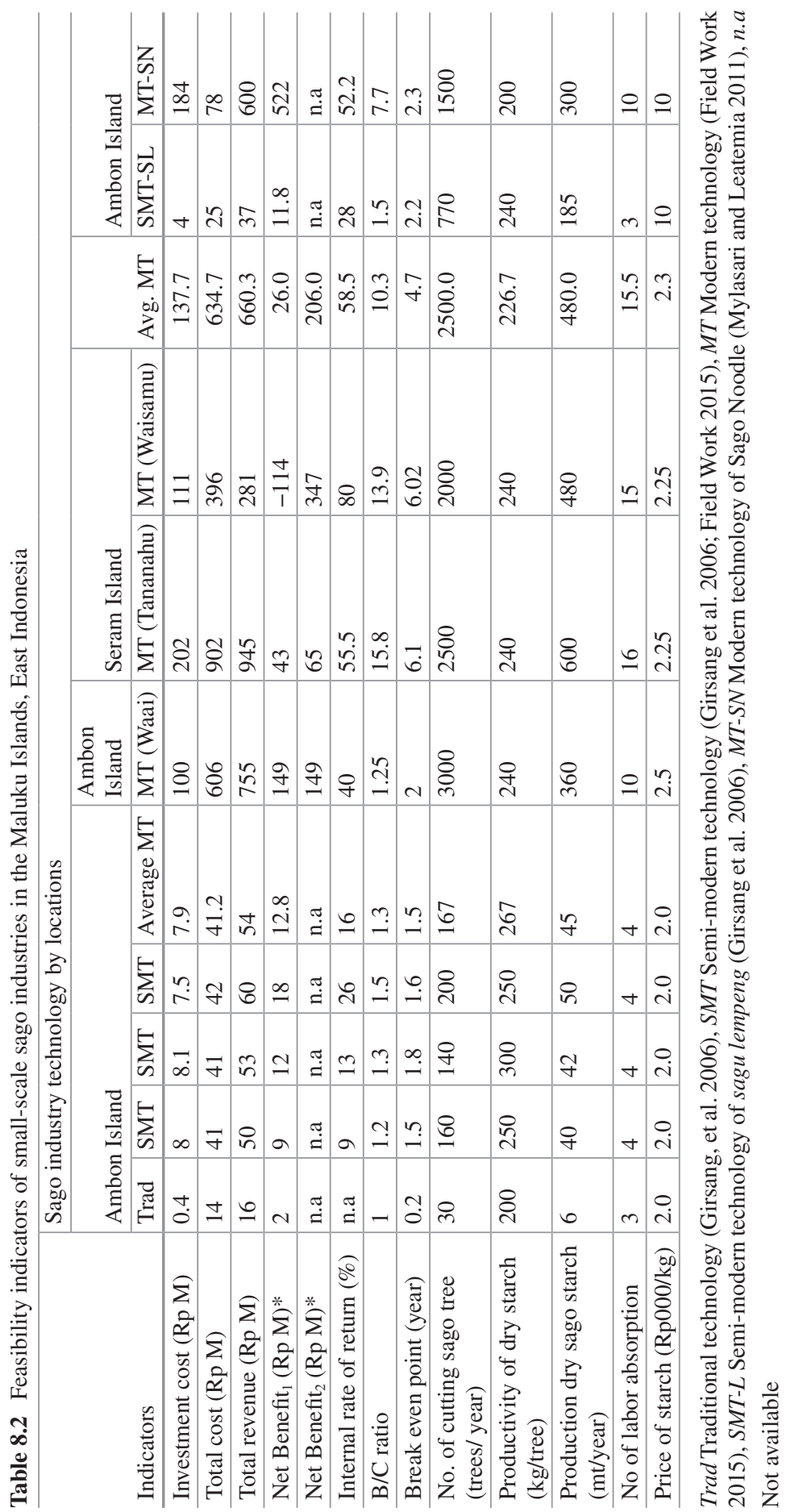




\subsubsection{Profitability of Small-Scale Sago Industries}

The main objective of sago industries is profitability. The annual net benefit of traditional and semi-modern technology is IDR 2 million and IDR 12.7 million, respectively, while the average net benefit of modern technology is IDR 26 and IDR 206 million in the first and second year of production, respectively. Traditional technology is subsistence oriented, for household consumption, whereas semi-modern and modern technologies are fully market oriented. Thus the benefit of the modern industry is almost eight times higher than that of semi-modern technology. In addition, the annual net benefit of sago lempeng (SL) and sago noodle (SN) industry is estimated at IDR 11.8 million and IDR 522 million, respectively. This means that the SN benefit is almost 44 times higher than semi-modern SL technology; however, the SN industry was unsustainable and failed due to compatibility and institutional constraints. In terms of compatibility, sago noodle industry failed to sustain because of ignored social preparation, human capital building capacity, and absenteeism of professional facilitators. In terms of institutional constraints, the sago noodle industry failed to sustain because sago farmer association, as the owner of the sago noodle industry, was unable to manage labor, private, and government intervention as well as to maintain and stabilize the price of sago starch.

Based on profitability indicators, all technology prototypes are feasible, particularly semi-modern and modern technologies. The highest total costs, revenue, and benefit of sago industries are found in the modern technology at Tananahu, followed by the modern sago industry in Waai and Waisamu villages. The amount of operational costs is determined by the distance and transportation cost to and from extraction site to sago forest, the price of raw material, and labor cost. To some extent, modern sago industries in Waisamu village operated at a loss in the first year (negative IDR 114 million) to pay for labor and high credit interest payment cost, but they achieved positive benefit in the second year (Table 8.2).

\subsubsection{Discussion}

The problem of food security in small islands is that the abundant local food resources like sago and the other local foods are abandoned by local people and replaced by imported rice (Girsang 2014). The area of rice fields in the Malukus is estimated at 22,470 ha (CBS 2014) with annual production around 73,028 $\mathrm{mt}$ or $45 \%$ of total annual rice demand of $161,213 \mathrm{mt}$ in 2015. As a result, the Malukus import $88,185 \mathrm{mt}$ of rice annually or $55 \%$ of total provincial rice consumption. Because the rice crop is vulnerable to pests and diseases as well as climate change impact, dependency on imported rice will create food insecurity over the long term in the islands. Thus sago forests need to be revitalized because they are environmentally friendly and suitable in small islands and sago starch is still the source of energy for $70 \%$ of people who live in remote rural areas on Seram Island, the largest of the Maluku Islands (Sasaoka and Loumonier 2011). 
Based on investment criteria, all types of sago industries were identified as financially feasible in the short term; however, these sago industries are challenged by financial, market, and institutional sustainability in the middle and longer term. Based on historical background, there are several reasons why sago industries failed to survive: (1) they are time-consuming and hard work; (2) they have high operational costs, especially labor, poor infrastructure and transportation, and high fuel and raw material costs (Louhenapessy 1992); (3) they have poor social preparation, ineffectiveness of farmer group institutions, and a low sago starch price (Mylasari and Leatemia 2011); and (4) there are uncertain sago land tenure status, failure to address sociocultural issues, and lack of the participation of local people.

Because of geographical landscape conditions, sago palm areas are spread over several regions, and each area is relatively small, growing naturally as sago forests on small islands. Therefore, it is inevitable that the rapidity of sago tree cutting by sago industries will exceed the natural regrowth of sago palm in an exploited area. As a consequence, the owner of a sago forest may decide to increase the price of sago trees. At this stage, the sago industry is vulnerable and hard to sustain because sago producers need more investment for equipment and operational cost to expand into the other sago forest land.

Therefore, to create a sustainable sago forest and sago industry, there needs to be a balance between sago supply and demand by creating sago clustering and rehabilitation zonation (Louhenapessy 2006; Girsang et al. 2010). Sago palm trees grow in clusters and each cluster consists of three to five trees with different age intervals of between 4 and 5 years. Each sago cluster is capable of self-regeneration; therefore, sago forests are sustainable because they do not need replanting and can be harvested regularly.

Due to poor infrastructure and accessibility to sago forests, existing sago industries need to be managed carefully to avoid an imbalance between the rate of cutting and the rate of regrowth. Other limiting factors are continuous supply of raw material, hilly topographical conditions, widely dispersed sago forest locations, and limited transport access within and between villages and islands. In addition, the land tenure status of sago forest needs to be made clear, otherwise sago land tenure and uncertain boundaries can be a source of social conflict. Basically, sago land tenure status can be categorized into three types, namely, (1) tanah negeri (village land), (2) tanah dati (family land), and (3) tanah pusaka (private land). This suggests that sago industrial development will need the certainty borders and status of sago forest land tenure to sustain sago production and to avoid social conflict.

\subsection{Conclusion}

The sago forest area in Maluku Province is estimated at 64,205 ha; however, the extent has probably been reduced to 44,944 ha because of sago land conversion into rice paddy, resettlement villages, offices, plantations, roads, and agriculture crops. It is concluded that existing traditional, semi-modern, and modern sago industries are financially feasible but vulnerably sustainable even though the whole sago 
exploitation rate in Malukus is estimated currently at only around 1597 ha/year or $3.6 \%$ of total sago forest area, and the remaining of $96.4 \%$ of sago forest area is unutilized with a theoretical annual economic loss around USD 260 million.

Traditional sago technology is being abandoned because it is time-consuming while semi-modern and modern sago industries are employed only in sago forest areas that have access to district or provincial capitals. This causes uneven exploitation of sago forests in the area and an unsustainable raw material supply because the rate of cutting will be faster than the rate of natural regrowth of sago trees. At the same time, sago industries are reluctant to operate in other inaccessible sago areas with poor infrastructure to avoid high operational costs, considering the low price of wet sago starch and limited demand for dry sago flour.

The other reasons for unsustainable sago industries are lack of financial capital and social preparation, failure to address cultural values, and lack of participation and facilitation of sago farmers and local people. As a result, most of sago forest areas are not utilized and are neglected. The central government probably prefers to promote replacement of sago forest areas with enlarged new rice fields to support the national rice production target; however, local governments should take affirmative action for food security and dignity based on sago and other local food resources, including revitalizing and promoting sustainable and feasible sago industries based on a sustainable landscape of sago forest areas on small islands.

Finally, sago forest is a natural resource endowment in the Malukus; therefore, the advancement of the sago forests and industries goes beyond food security. Sago forests need to be developed under a zero waste sago industry model that will produce healthy food, sugar, and biofuel (Ishizaki 1997; Bujang 2010) and create stable agroforestry systems (Stanton 1993) that are more resistant to climate change impacts. Moreover, the role of sago forests will bridge, bond, and link the forests, agriculture and fisheries, mangrove and coral reefs to support sustainable integrated community-based resource management landscapes in small islands. This goes beyond Provincial Government Regulations number 110/2011 that focus on sustainable sago forest exploitation and central government regulations in line with accelerating local food consumption diversification (Indonesia 2009). To achieve sustainable sago forests and industries as well as to protect the environment of small islands, the government needs to boost rural infrastructural development in each sago area, including incentives and law enforcement, human capital and capacity building, social and political stability, communications, tax holidays, and financial institutional support.

\section{References}

Alfons JB, Bustaman S (2005) Prospect and direction of sago development in Maluku. The Agricultural Research and Dissemination Agency, Ambon. [In Indonesian]

Amien I (2011) Coping with climate change. Paper presentation at: the future of global food security and safety: issues and justification. IPB International Convention Center, 27 October 2011, Bogor 
Bintoro MH (2011) Progress of sago research in Indonesia. In: Siregar ZI et al. (eds) The 10th international Sago Symposium "Sago for food security, bio-energy and industry: from research to market", IPB international convention center-The Indonesian Sago Palm Society, Bogor

Bintoro MH, Amarilis S, Kemala Dewi R, Ahyuni D (2013) The forgotten equator-green pearl sago. IPB Press, Bogor

BPPS (2009) Mapping and potential stockpile of Sago Palm in Tutuk Tolu-Eastern Seram, Western Seram, Saparua-Central Seram, and Namrole-Southern Buru islands. Research Report. Cooperation Project Research of Maluku Province Agricultural Agency Office and Maluku Sago Research and Development Board, Ambon. Maluku. (in Indonesian)

Bujang K (2010) Production and processing of sago: a food and fuel alternative. Paper presented at International seminar on sago and spices for food security, Swissbel Hotel, Ambon, 28-29 July, 2010

CBS (2012) Maluku in figures. Statistical Centre Board and Maluku Regional Development Planning Agency, Ambon, Maluku

CBS (2014) Central Board of Statistics, Maluku Province in figures. Cooperation-Provincial Statistic Center Agency and Regional Development Plan Board, Ambon. http://maluku.bps. go.id

Ellen R (2006) Local knowledge and management of sago palm (Metroxylon sagu Rottboell) diversity in South Central Seram, Maluku, Eastern Indonesia. J Ethnobiol 26(2):258-298

Field Work (2015) Notes on field observation of Sago industries in Western and Central Seram island, Ambon. Maluku (In Indonesian)

Flach M (1984, January 16-21) Agronomy of sago based on cropping system: a preliminary approach. In: Proceedings of the The FAO/BPPT expert consultation on the development of sago palm and palm product. Jakarta

Flach M (1997) Sago palm. Metroxylon sagu Rottb. Promoting the conservation and use of underutilized and neglected crops, Pub. No. 3. Institute of Plant Genetics and Crop Plant Research, International Plant Genetic Resources Institute, Rome

Girsang W (2006) Feasibility study of sago, bamboo and cajuput oil: start-up small scale business. Final Report for United Nations Industrial Development Organization (UNIDO), Maluku, Ambon

Girsang W (2014) Socio-economic factors that have influenced the decline of sago consumption in small islands: a case in rural Maluku, Indonesia. S Pac Stud 34(2):99-116

Girsang W, Papilaya EC (2009) Improvement of sago competitiveness for food security in Maluku. In: Lilis N (ed) Proceeding: investing in food quality, safety and nutrition. Southeast Asian Food Science and Technology (SEAFAST) Centre, Bogor Agricultural University, Bogor

Girsang W, Rumalatu FJ, Louhenapessy JE et al (2010) Sago in Maluku: policies, potential, processing and social economic. Paper presented at The International seminar on spices and sago for food security to support Sail Banda Programs, 28 July 2010, Swissbel Hotel, Ambon

Haryanto B, Pangloli P (1992) The potential and use of sago. Kanisius, Jakarta. [In Indonesian]

Ibrahim (1985) Introduction to the project evaluation. Gramedia, Jakarta. [In Indonesian]

Indonesia (2009) President of Republic of Indonesia Regulation No. 22 Year 2009 on the Acceleration of food consumption diversification based on local resources [In Indonesian]

Ishizaki A (1997) Concluding remarks for the 6th International Sago Symposium. Riau Indonesia. Sago Commun 8(2):22-24

Jong FS, Widjoyo A (2007) Sago: the big potential of agriculture in Indonesia. Sci Tech Food 2(1):59-65. (In Indonesian)

Louhenapessy JE (1992) Sago in Maluku: its potential, land condition and its problem. National Symposium of Sago, Faculty of Agriculture, University of Pattimura [In Indonesian]

Louhenapessy JE (2006) Potential and management of sago in Maluku Proceedings, sago workshop, revitalization of agriculture in Maluku, Ambon 29-31 May 2006. Faculty of Agriculture University of Pattimura Press, Ambon [In Indonesia]

Mylasari R, Leatemia E (2011) Feasibility study of sago noodle project in Tulehu village, Central Maluku. Unpublished research report. Research Institution University of Pattimura, Ambon [In Indonesian] 
National Food Security Board (2011) Reality and expectation of food diversification. Paper presented in International seminar on the future of global food security and safety: issues and justification. IPB Convention Centre, Bogor, Indonesia

Papilaya EC (2009) Sago for the country people education. IPB Press, Bogor. [In Indonesian]

Rumalatu FJ (1992) Sago in Maluku: past, present and future prospect. J Cakalele, vol 3. The University of Hawai'i at Manoa. pp 64-67

Sasaoka M, Laumonier Y (2011) The influence of 'sago-based vegeculture' on forest landscapes in central Seram, eastern Indonesia. Paper presentation at The 10th International Sago Symposium, 29-30 October 2011. IPB International Convention Center, Bogor

Stanton WR (1993) Perspectives on, and future prospects for, the sago palm. Sago Palm 1:2-7

Yamamoto Y (2011) Starch productivity of sago palm and related factors. In: Proceeding of the 10th international sago symposium Bogor, Indonesia, pp 10-15

Open Access This chapter is licensed under the terms of the Creative Commons Attribution 4.0 International License (http://creativecommons.org/licenses/by/4.0/), which permits use, sharing, adaptation, distribution and reproduction in any medium or format, as long as you give appropriate credit to the original author(s) and the source, provide a link to the Creative Commons license and indicate if changes were made.

The images or other third party material in this chapter are included in the chapter's Creative Commons license, unless indicated otherwise in a credit line to the material. If material is not included in the chapter's Creative Commons license and your intended use is not permitted by statutory regulation or exceeds the permitted use, you will need to obtain permission directly from the copyright holder.

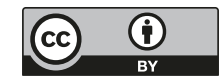

